\title{
Price-to-earnings ratio: A state-of-art review
}

\author{
Mohammad Reza Ghaeli*
}

Adjunct Professor, School of Management, New York Institute of Technology, 1700 - 701 W Georgia St., Vancouver, BC V7Y 1 K8 Canada

\section{H R O N I C L E}

\begin{tabular}{l}
\hline Article history: \\
Received December 5, 2014 \\
Received in revised format \\
February 162016 \\
Accepted July 12016 \\
Available online \\
July 27 2016 \\
\hline Keywords: \\
Price-to-earnings \\
P/E ratio \\
Stock exchange \\
\hline
\end{tabular}

\begin{abstract}
A B S T R A C T
One of the primary tools for asset evaluation on stock market is to use price-to-earnings (P/E) ratio. The method is simple and has become popular among many investors for buy/sell decisions. In this paper, we present a comprehensive review on recent advances on the use of $\mathrm{P} / \mathrm{E}$ ratio for measuring other firms' characteristics. The survey has reviewed several studies on the relationship between $\mathrm{P} / \mathrm{E}$ ratio and stock performance, estimation of transaction data, insider transaction, future growth, firm size, interest ratio, book-to-market equity, etc.
\end{abstract}

\section{Introduction}

O 2017 Growing Science Ltd. All rights reserved.

The price-earnings ratio ( $\mathrm{P} / \mathrm{E}$ Ratio) is the ratio for assigning a value for a firm that measures its current share price relative to its per-share earnings (Nicholson, 1960). The price-earnings ratio is normally calculated as the market value per share divided by earnings per share. There are several methods for calculating P/E ratios. EPS is normally extracted from the recent 4 quarters, which forms trailing P/E ratios and it can be measured by subtracting a firm's share value at the start of the 12-month period from its value at the period's end, adjusting for stock splits in case there is any. Another form of P/E ratio is associated with analysts' prediction of earnings anticipated during the next 4 quarters called projected or forward P/E (Nicholson, 1960). Normally, a high P/E ratio implies that investors are anticipating higher earnings growth within the next years while firms with a lower $\mathrm{P} / \mathrm{E}$ are expected lower growth. In fact, a low $\mathrm{P} / \mathrm{E}$ indicates either a firm is presently undervalued or it is performing exceptionally well relative to its past trends (Goodman \& Peavy III, 1986). Most researchers believe value shares will definitely outperform glamour shares in the long term but the reason on why glamour shares remain popular stays behind the $\mathrm{P} / \mathrm{E}$ ratio to discriminate between the value asset versus glamour one (Anderson \& Zastawniak, 2016). According to Deaves et al. (2008) a significant variation in the

\footnotetext{
* Corresponding author.

E-mail address: rghaeli@nyit.edu ( R Ghaeli)

(C) 2017 Growing Science Ltd. All rights reserved. doi: $10.5267 /$ j.ac.2016.7.002
} 
Canadian E/P ratio can be described by a combination of the lagged level of the E/P in coordination to variability in logical explanatory factors.

When a firm has no earnings or is reporting losses, $\mathrm{P} / \mathrm{E}$ will not be available and this measure cannot be used for asset evaluation. Theoretically, by taking the mean/median of $\mathrm{P} / \mathrm{E}$ ratios over a long period of time, we may reach to a standardized $\mathrm{P} / \mathrm{E}$ ratio considered as a benchmark and learn more about whether or not a firm can be considered as a buying opportunity (Wisniewski et al., 2012). The P/E ratio changes from one sector to another one and, thus, when we compare two firms in two various sectors, it is not wise to look at $\mathrm{P} / \mathrm{E}$ ratios to compare two firms. An individual firm's $\mathrm{P} / \mathrm{E}$ ratio is meaningful when considered with $\mathrm{P} / \mathrm{E}$ ratios of other firms within the same sector. For instance, a firm in energy sector normally yields a high $\mathrm{P} / \mathrm{E}$ ratio, but this may reflect a trend within the sector rather than one solely within the individual firm ${ }^{1}$. Fig. 1 demonstrates the average P/E ratio from 1871 to 2016 for Standard \& Poor 500 (S\&P 500).

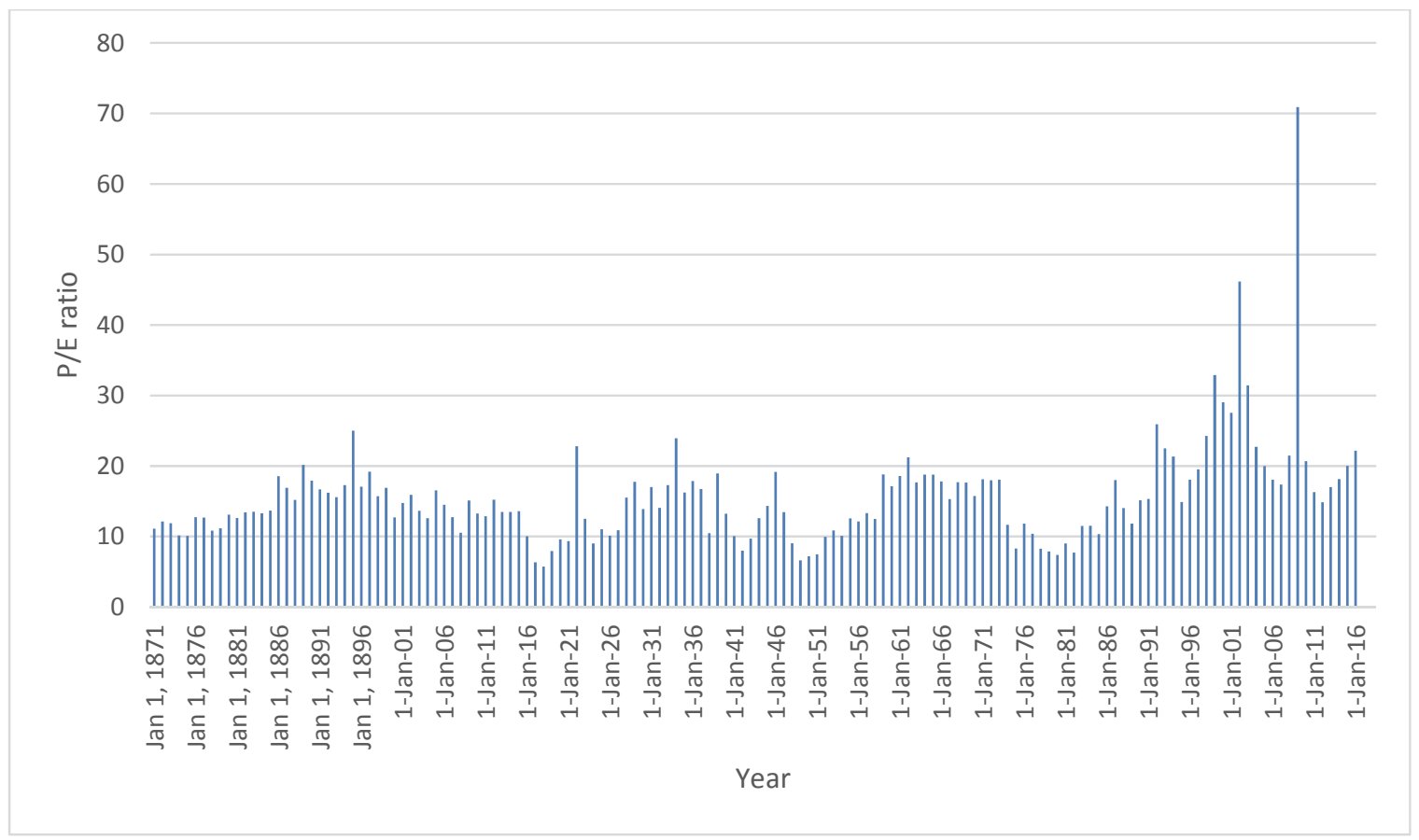

Fig. 1. Average P/E ratio of S\&P 500 from 1871 to 2016

Source: http://www.econ.yale.edu/ shiller/data.htm

As we can observe from the figure, the average $\mathrm{P} / \mathrm{E}$ ratio has fluctuated year over year from 5.31 in December, 1917 to 123.73 in May, 2009. In addition, the mean and median of the P/E ratio were 15.60 and 14.63, respectively. Another observation is that when the $\mathrm{P} / \mathrm{E}$ ratio is relatively high, this does not mean that the bull session continues for good and when it is low it also does not mean that the bear session continuous forever (French \& Poterba, 1991). There are literally different technical indicators for detecting buy/sell on stock market including moving average, relative strength index, stochastic oscillator, etc.

\section{2. $\mathbf{P} / \mathbf{E}$ ratio}

Basu (1977) is believed to be the first who tried to detect whether or not the investment performance of common stocks is associated with their P/E ratios. Penman (1996) made an assessment on the relationship between the $\mathrm{P} / \mathrm{E}$ ratio and the market-to-book ratio $(\mathrm{P} / \mathrm{B})$ and how both ratios was 
associated with current and future earnings growth. He reported that $\mathrm{P} /$ Es were associated with current return on equity but were poor indicators of future growth, and $\mathrm{P} / \mathrm{Bs}$ yielded the effect of future profitability and were good indicators of earnings growth. Cook and Rozeff (1984) investigated the implied standard deviation (ISD) estimated from transactions data on options, based the Black-Scholes pricing model. They reported that the distribution of the ISD was symmetric but not normal. In addition, the ISD based on the last daily observation deviated substantially from the daily average ISD. Beaver and Morse (1978) reported that evident persistence in $\mathrm{P} / \mathrm{E}$ ratios is neither growth nor risk but differences in accounting method. In stock market companies with low $\mathrm{P} / \mathrm{E}$ ratios earn higher stock returns in the long term than high growth firms with high $\mathrm{P} / \mathrm{E}$ ratios.

Houmes and Chira (2015) studied how insider ownership could possibly influence on this relation by describing that when insider ownership is high, returns reduce for low $\mathrm{P} / \mathrm{E}$ companies and help for high $\mathrm{P} / \mathrm{E}$ firms. For low $\mathrm{P} / \mathrm{E}$ companies, low stock returns represent the inability of boards of directors and outside shareholders to affect poorly performing entrenched management. Chen et al. (2015) investigated whether predicting future earnings can create risk-adjusted returns. We find that the riskadjusted returns of portfolios constructed on future E/P ratios are superior to those constructed on past $\mathrm{E} / \mathrm{P}$ ratios under the four-factor model. The risk-adjusted returns increase monotonically with the number of future quarters used to compute the E/P ratios. Moreover, the risk-adjusted returns for the firms with high $\mathrm{E} / \mathrm{P}$ ratios are positively related to the changes between past earnings and future earnings. Overall, forecasting future earnings precisely would significantly enhance the risk-adjusted returns of portfolios.

$\mathrm{Wu}(2014)$ reported that the forward earnings per price $(\mathrm{E} / \mathrm{P})$ ratio was a stronger estimator of future growth than the traditionally used trailing E/P ratio. Baker et al. (2013) investigated trends in farmland values, cash rents, interest rates, the farmland price to cash rent $(\mathrm{P} / \mathrm{Rent})$ multiple, and the $\mathrm{P} / \mathrm{E}$ ratio on stocks. The P/Rent multiple averaged 17.6 over the period 1960-2012 and ranged from 11.1 in 1986 to 29.5 in 2012 . Firms of the $\mathrm{P} /$ Rent ratio to the $\mathrm{P} / \mathrm{E}$ ratio provided that the present $\mathrm{P} /$ Rent ratio was above the current $\mathrm{P} / \mathrm{E}$ ratio and substantially above both the long-term $\mathrm{P} /$ Rent and $\mathrm{P} / \mathrm{E}$ ratios.

According to Chhaya and Nigam (2015) value strategies based on low price relative to earnings, dividends, book value and other fundamental measures, could outperform the corresponding 'growth strategies' and the market. They tried to study this premise in the Indian context by forming equity portfolios based on $\mathrm{P} / \mathrm{E}$ ratios and evaluated their ex post returns on both absolute and risk adjusted measures. They reported some evidence of statistically substantially value premium in the Indian stock market.

Arslan et al. (2014) analyzed the effect of dividend yield and P/E ratio on stock returns and determined the relationship between size and stock price based on the data from 111 non-financial KSE listed firms over the period 1998-2009. They reported that P/E ratio and size of firm had substantial positive effect on stock prices. They also reported negative relationship between dividend yield and stock prices. Their results also recommended that investors could use investment criteria that include size of firm and $\mathrm{P} / \mathrm{E}$ ratio anomalies to earn abnormal return.

Al-Mwalla et al. (2010) investigated long run relationship between stock prices, P/E, dividend yields and size of firms and reported Jordan Stock Market faced informational lack of efficiencies and business managers and investors started their investment by utilizing $\mathrm{P} / \mathrm{E}$ and size anomalies to earn abnormal returns. San Ong et al. (2010) investigated the ability of value investing strategy on forecasting stock performance in terms of the fall in stock prices in Malaysia by observing the development of the Malaysian stock market index, the Kuala Lumpur Composite Index (KLCI) and its $\mathrm{P} / \mathrm{E}$ ratio over the period 1994-2010, when there was a financial crisis of the 1997/98 Asian financial crisis and the global financial crisis of late. The results indicated that $\mathrm{P} / \mathrm{E}$ ratio could provide good insight on the performance of KLCI. 
Lam (2002) studied the relationship between stock returns and $\beta$, size (ME), leverage, book-to-market equity ratio, and earnings-price ratio $(\mathrm{E} / \mathrm{P})$ in Hong Kong stock market based on the Fama and French (1992) approach. Fama and French (1992) reported that two variables, size and book-to-market equity, combine to reach the cross-sectional variation in average stock returns related to $\beta$, size, leverage, bookto-market equity, and $\mathrm{E} / \mathrm{P}$ ratios. Lam (2002 reported that $\beta$ was unable to provide the average monthly returns on stocks continuously listed in Hong Kong Stock Exchange. However, three of the variables, size, book-to-market equity, and $\mathrm{E} / \mathrm{P}$ ratios, appeared to capture the cross-sectional variation in average monthly returns. They also recommended that their results were not driven by extreme observations or abnormal return behavior for some of the months or by size groups.

Lafmejani (2017) presented a survey to learn whether or not there is any difference between the returns of two value and growth portfolios, sorted by $\mathrm{P} / \mathrm{E}$ and price-to-book value $(\mathrm{P} / \mathrm{BV})$, according to the ratios of market sensitivity to index $(\beta)$, firm size and market liquidity in listed firms in Tehran Stock Exchange (TSE) from 2001 to 2008. The selected companies were chosen from those with existing two-consecutive positive $\mathrm{P} / \mathrm{E}$ and $\mathrm{P} / \mathrm{BV}$ ratios and by excluding financial and holding firms. There were five independent variables for the proposed study of this paper including $\mathrm{P} / \mathrm{E}, \mathrm{P} / \mathrm{B}$, market size, market sensitivity beta $(\beta)$ and market liquidity. For each year, they first sort companies in non-decreasing order and setup four set of portfolios with equal companies. Thus, the first portfolio with the lowest $\mathrm{P} / \mathrm{E}$ ratio was called value portfolio and the last one with the highest $\mathrm{P} / \mathrm{E}$ ratio was named growth portfolio and repeated the process based on $\mathrm{P} / \mathrm{BV}$ ratio to detect value and growth portfolios, accordingly. The study studied the characteristics of two portfolios based on firm size, $\beta$ and liquidity and their results indicated mix effects of market sensitivity, firm size and market liquidity on returns of the firms in various periods.

Lau et al. (2002) investigated the relationship between stock returns and beta, size, the E/P ratio, the cash flow-to-price ratio, the book-to-market equity ratio, and sales growth (SG). They reported the existence of anomalies in these emerging markets based on the data from Singapore and Malaysia for the period 1988-1996 and reported a conditional relationship between beta and stock returns for both countries. During months with positive market excess returns, there was a substantial positive relationship. They also reported a negative link between beta and stock returns when market faced with negative signals. They documented a negative effect of stock returns on size for both countries. For Singapore, they also reported a negative relationship between returns and SG while in Malaysia, they reported a positive relationship between returns and the E/P ratio.

Weigand and Irons (2007) investigated the market P/E ratio and its relationship to future stock return, aggregate earnings and interest rates in the US market. They forecasted of ten-year real stock returns based on the level of the market earnings yield (E/P ratio or $\mathrm{P} / \mathrm{E}$ ratio), and determined that their predictions were not as bad as those made in other modes. Estrada (2005) compared the performance of a low-P/E strategy relative to that of two alternative value strategies, one based on the PEG ratio and another on the PERG ratio. They reported that the ones sorted by PERG ratios could perform better than the one based on both $\mathrm{P} / \mathrm{E}$ ratios and $\mathrm{PEG}$ ratios.

Weske and Benuto (2015) performed an empirical investigation to determine a fraud based on the changes in share price and $\mathrm{P} / \mathrm{E}$ ratios prior to a public announcement for a sample firms selected from US matket between 2000 and 2004. They reported a substantial relationship between firms prosecuted for fraud and the coefficient of variation. However, the relationship between the price/earnings ratio and firms prosecuted for fraud was insignificant.

According to Zorn et al. (2009), the P/E ratio is normally implemented as a metric to compare individual stocks and the market as a whole relative to historical valuations. Zorn et al. (2009) investigated the factors that influence changes in the inverse of the $\mathrm{P} / \mathrm{E}$ ratio $(\mathrm{E} / \mathrm{P})$ over time in S\&P 500 Index. The proposed model included variables which measure investor beliefs and changes in tax rates and indicated that these variables were essential factors influencing on the $\mathrm{P} / \mathrm{E}$ ratio. They extended prior work by modifying for the presence of a long-run relationship between variables included in their model 
and reported that changes in the $\mathrm{P} / \mathrm{E}$ ratio had some predictive power. The model also described a large portion of the variation in $\mathrm{E} / \mathrm{P}$ and accurately forecasted the future direction of $\mathrm{E} / \mathrm{P}$, specifically when forecasted changes in $\mathrm{E} / \mathrm{P}$ were large or gave a consistent signal over more than one quarter.

\section{Summary}

In this paper, we have discussed the merit of simple ratio on predicting market value, detecting bull/bear session and even predicting fraud in earnings announcement. The survey has reviewed several studies on the relationship between $\mathrm{P} / \mathrm{E}$ ratio and stock performance, estimation of transaction data, insider transaction, future growth, etc. The study has covered a wide scope of studies performed on different stock exchanges.

\section{Acknowledgement}

The authors would like to thank the anonymous referees for constructive comments on earlier version of this paper.

\section{References}

Anderson, K., \& Zastawniak, T. (2016). Glamour, value and anchoring on the changing P/E. The European Journal of Finance, 1-32.

Arslan, M., Zaman, R., \& Phil, M. (2014). Impact of dividend yield and price earnings ratio on stock returns: A study non-financial listed firms of Pakistan. Research Journal of Finance and Accounting), ISSN, 2222-1697.

Baker, T., Langemeier, M., \& Boehlje, M. (2013). Farmland price to earnings ratios for Indiana. Center for Commercial Agricultural Business, Purdue University.

Basu, S. (1977). Investment performance of common stocks in relation to their price-earnings ratios: A test of the efficient market hypothesis. The journal of Finance, 32(3), 663-682.

Beaver, W., \& Morse, D. (1978). What determines price-earnings ratios?.Financial Analysts Journal, 34(4), 65-76.

Cook, T. J., \& Rozeff, M. S. (1984). Size and earnings/price ratio anomalies: one effect or two?. Journal of Financial and Quantitative Analysis, 19(4), 449-466.

Chen, L. W., Yu, H. Y., \& Huang, H. H. (2015). Revisiting the earnings-price effect: The importance of future earnings. Finance Research Letters, 13, 90-96.

Chhaya, G., \& Nigam, P. (2015). Value investing with price-earnings ratio in India. IUP Journal of Applied Finance, 21(2), 34.

Deaves, R., Miu, P., \& White, C. B. (2008). Canadian stock market multiples and their predictive content. International Review of Economics \& Finance,17(3), 457-466.

Estrada, J. (2005). Adjusting P/E ratios by growth and risk: the PERG ratio.International Journal of Managerial Finance, 1(3), 187-203.

Fama, E. F., \& French, K. R. (1992). The cross-section of expected stock returns. The Journal of Finance, 47(2), 427-465.

French, K. R., \& Poterba, J. M. (1991). Were Japanese stock prices too high?. Journal of Financial Economics, 29(2), 337-363.

Goodman, D. A., \& Peavy III, J. W. (1986). The interaction of firm size and price-earnings ratio on portfolio performance. Financial Analysts Journal,42(1), 9-12.

Houmes, R., \& Chira, I. (2015). The effect of ownership structure on the price earnings ratio-returns anomaly. International Review of Financial Analysis, 37, 140-147.

Lam, K. S. (2002). The relationship between size, book-to-market equity ratio, earnings-price ratio, and return for the Hong Kong stock market. Global Finance Journal, 13(2), 163-179.

Lafmejani, M. (2017). The relationship between size, book-to-market equity ratio, earnings-price ratio, and return for the Tehran stock Exchange.Accounting, 3(1), 11-18.

Lau, S. T., Lee, C. T., \& McInish, T. H. (2002). Stock returns and beta, firms size, E/P, CF/P, book-tomarket, and sales growth: evidence from Singapore and Malaysia. Journal of multinational financial management, 12(3), 207-222. 
Al-Mwalla, M., Al-Omari, A. M., \& Ayad, F. (2010). The relationship between P/E ratio, dividend yield ratio, size and stock returns in Jordanian companies: A co-integration approach. International Research Journal of Finance and Economics, 49(7), 87-103.

Nicholson, S. F. (1960). Price-earnings ratios. Financial Analysts Journal,16(4), 43-45.

Penman, S. H. (1996). The articulation of price-earnings ratios and market-to-book ratios and the evaluation of growth (digest summary). Journal of Accounting Research, 34(2), 235-59.

San Ong, T., Yichen, Y. N., \& Teh, B. H. (2010). Can high price earnings ratio act as an indicator of the coming bear market in the Malaysia?.International Journal of Business and Social Science, 1(1), 194-213.

Weigand, R. A., \& Irons, R. (2007). The market p/e ratio, earnings trends, and stock return forecasts. Journal of Portfolio Management, 33(4), 87.

Weske, J., \& Benuto, L. (2015). Share prices and price/earnings ratios as predictors of fraud prior to a fraud announcement. Academy of Accounting and Financial Studies Journal, 19(2), 281.

Wisniewski, T. P., Lightfoot, G., \& Lilley, S. (2012). Speculating on presidential success: exploring the link between the price-earnings ratio and approval ratings. Journal of Economics and Finance, 36(1), 106-122.

$\mathrm{Wu}, \mathrm{W}$. T. (2014). The forward E/P ratio and earnings growth. Advances in Accounting, 30(1), 128142.

Zorn, T., Dudney, D., Jirasakuldech, B. (2009). P/E changes: Some new results. Journal of Forecasting, 28 (4), 358-370 